\author{
A. V. Diachkova, D. G. Sandler, E. S. Avramenko
}

\title{
Case of using simulation in education for business analysts
}

\section{KEYWORDS}

simulation;

gamification;

digital ed-technology;

economic education;

business analysist

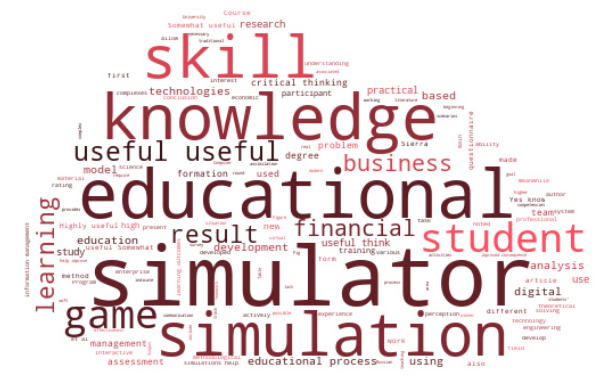

Word Cloud Generated by:

https://wordscloud.pythonanywhere.com/

\section{ABSTRACT}

Introduction. Nowadays, the world and domestic education system is following the path of innovative development. New interactive and digital ed-technologies are being actively developed and implemented. One of them is simulation designed to form practice-oriented competencies for students. It requires both a design and analysis of the technologies themselves and an assessment of their implementation. The aim of the article is to estimate the experience of using the simulator in educational process for business analysts.

Materials and methods. The research is based on standard methods of scientific analysis: evolutionary approach, comparative analysis. The empirical part of the study included conducting an experiment. The Program Complex "Business Course: Corporation plus", group version was used as a training simulator. Assessment of the educational effect from the use of the simulator, the degree of involvement and interest of students in the educational process, the level of assimilation of the acquired knowledge were obtained using questionnaires and testing.

Results and discussion. The use of a business game simulator can be successfully integrated into the educational process for economic and financial program in the university. Corresponds to educational tasks, it allows not only to form professional competencies, but also soft skills necessary in a dynamically changing professional environment.

Meanwhile, the introduction of simulators into the educational process will require high-quality methodological training, development of recommendations for game managers, as well as cooperation with real enterprises that could modify educational and practical tasks.

Conclusions. The results of the present research indicate the readiness of students to use new educational technologies in forming professional knowledge and skills, their active involvement and interest in the educational process using the simulator

Diachkova, A. V., Sandler, D. G., \& Avramenko, E. S. (2020). Case of using simulation in education for business analysts. Economic consultant, 31 (3), 104-114. doi: 10.46224/ecoc.2020.3.7 


\section{INTRODUCTION}

$\mathrm{N}$ owadays, the world and domestic education system is following the path of innovative development. New interactive and digital technologies are being actively developed and implemented. One of them is simulators designed to form practice-oriented competencies for students. The higher education system was one of the first to respond to this challenge, and is actively beginning to introduce new digital and interactive models.

At present, the Government of the Russian Federation has developed the National Program "Digital Economy of the Russian Federation", its implementation period is from October 2018 to 2024. In accordance with it, a course is set in the education system for the formation of digital educational and methodological complexes and educational simulators, virtual laboratories for implementation in educational institutions [13].

The speed of this process directly depends on the financial and human resources of the organization. They are needed to purchase equipment, communications, attract specialists, and develop teaching methods using digital complexes.

It should be noted that not all universities are ready for such innovations, primarily due to the lack of financial resources. The problem is compounded by the lack of methodology for using digital educational complexes in the classroom. At the same time, the development of new methodological support using digital technologies, the assessment of the achievements of learning outcomes requires significant labor costs from teachers $[2 ; 11]$. This hinders the movement of the educational institution towards the digitalization of education.

Therefore, the task should be reduced to the development of methodological support for digital complexes in the educational process. Further, it is necessary to assess the effectiveness of the use of this digital educational technology, which would reflect the assimilation of the material by students, the ability to apply the necessary theoretical knowledge for practical analysis, but the degree of students' interest in learning new material is no less important. The relevance of the problem of introducing digital technologies into the educational process determined the choice of the goal, subject and methods of this research.

Aim of the study: to estimate the experience of using the simulator in the educational process for business analysts.

\section{MATERIALS AND RESEARCH METHODS}

The research is based on standard methods of scientific analysis: evolutionary approach, comparative analysis, questionnaires. The empirical part of the study included conducting an experiment.

The study was attended 3rd year students of the educational program "Applied Economics and Finance" (03.38.01 "Economics"), of the Ural Federal University named after the first 
President of Russia B. N. Yeltsin (Yekaterinburg), 53 people. The Program Complex "Business Course: Corporation plus", group version (developed by Lomonosov Moscow State University and LLC "Higher Computer Courses of Business") was used as a training simulator.

Working with a simulator involves managing a virtual enterprise operating in a competitive environment. The programs include an integral assessment of management efficiency, game rating.

Assessment of the educational effect from the use of the simulator, the degree of involvement and interest of students in the educational process, the level of assimilation of the acquired knowledge was based on the approach of Byers et al, Peak \& Hoffman, Sierra, which involves questioning the participants in the learning process using simulators and monitoring the assimilation of knowledge $[4 ; 14 ; 18]$.

Based on test items, the formation of knowledge and understanding was checked. The game manager assessed information management skills, critical thinking skills, taemworks during the game. A 10-point scale was used.

\section{ANALYSIS OF THE LITERATURE}

Researches in the field of digital and interactive educational technologies can be conditionally divided into two main tracks. The first is a design of these technologies, maps for instructor and gamers. The second track is the assessment of students' perception of the educational technologies used. This can be concluded from the review by Chin et al [5].

In the study by Kirillova et al, it is noted that today in the educational segment, the main trend is connected with blended learning, gamification and simulation, practical orientation models. Simulation is a perspective educational technology that forms the student's practical experience, while there is a possibility of different scenarios for the development of the situation and their assessment [10].

Mohammadyari \& Singh emphasized that the main educational tasks of simulators are reduced to the transformation of theoretical concepts into practical actions, the formation of a stable way of actions for solving specific practical problems [12].

The use of simulators in the educational process is reflected in publications. The analysis of articles in the field of simulation in education in the Scopus database allows to conclude that the first works on the analysis of the experience of implementing simulators began to appear back in the 1960s and 70s. In those days, simulators were as an exercise equipment (for technical sciences) and games based on developed scenarios (for social sciences). Computerization made it possible to develop more complex, but close to reality simulation models. The same conclusion was reached in the study by Hallinger and Wang. The authors identified 2,812 Scopus-indexed Simulation-based learning (SBL) documents published between 1965 and 2018. The review showed that the publishing track is growing rapidly: $90 \%$ of the literature has been published since 2000. Although SBL research has been conducted in 94 countries, 
the literature is concentrated in Anglo-American-European societies. The intellectual structure of this knowledge base covers to a greater extent the research of simulators in management and medical education [7].

It should be added that according to the profile of articles compiled in the present article by areas of knowledge in the Scopus database (Fig. 1), simulators are actively implemented in computer science, social sciences and engineering.

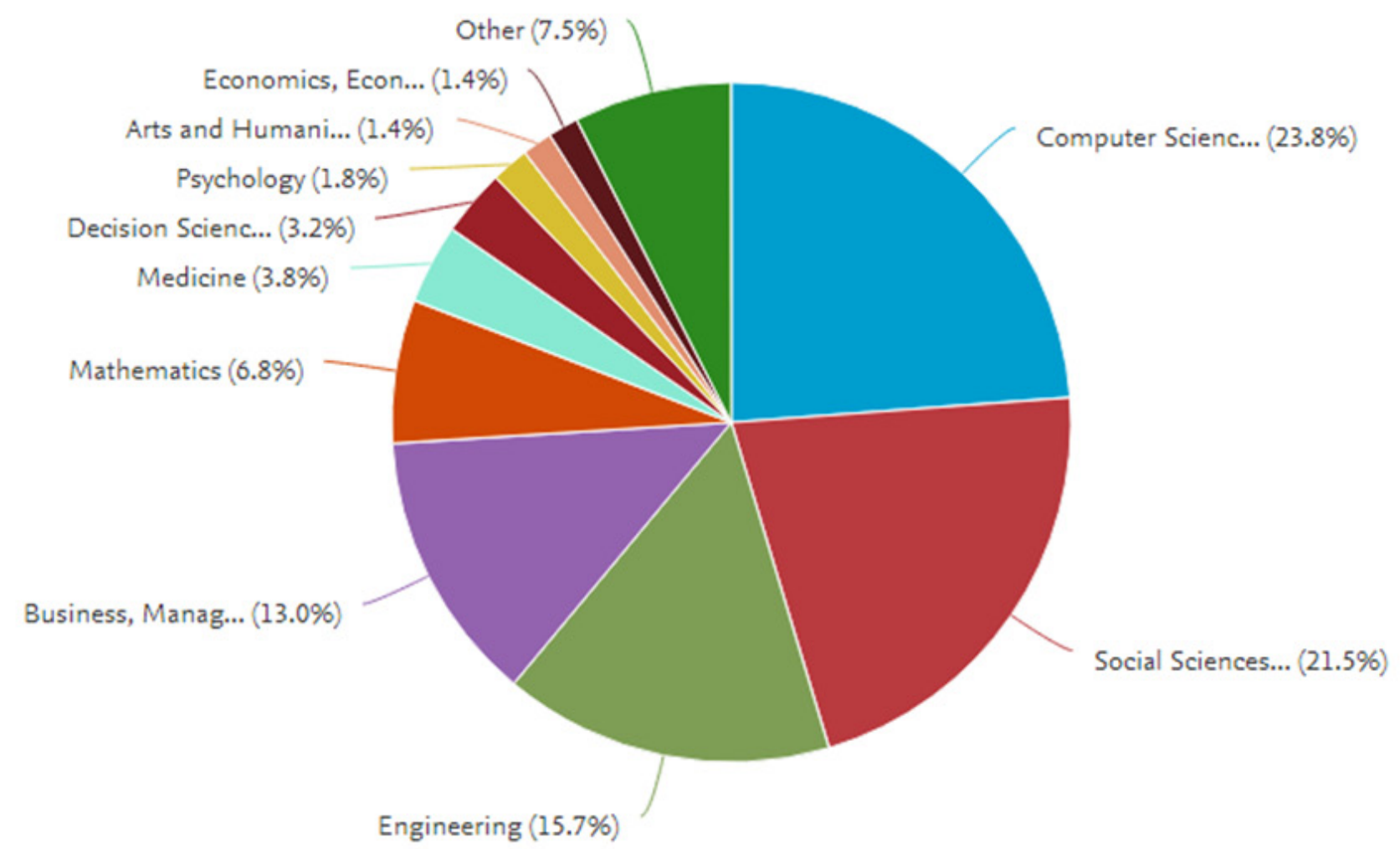

Figure 1 Subject areas of Articles about simulation in education [15]

Shurov, Vaulin [17, p. 79] indicate that modern Computer-aided engineering (CAE) systems of engineering analysis have become pilot in the educational process. When software packages are used to solve engineering calculations and simulation training is introduced.

Stošić emphasizes the need to use different simulator models with different levels of realism in the educational process. This allows solving educational problems of varying complexity [19]. It can be added that the availability of different simulator models also provides financial flexibility, makes it possible to purchase inexpensive simplified models or complex expensive models.

Research by $\mathrm{Li}$ et al is focused on assessing the effectiveness of using a virtual simulator in comparison with traditional forms of organizing student activities aimed at gaining practical experience [11]. The assessment is given through a questionnaire survey of students. Conclusions were made about the interest of students in this format of education.

The use of simulators provides the formation of real production knowledge. Ullah examines the degree of knowledge formation among students based on simulation learning. It contributes to the formation of various types of knowledge: analytical a priori knowledge, synthetic a priori 
knowledge, synthetic a posteriori knowledge, meaningful knowledge and skeptical knowledge. The author summarizes that on the basis of this it is necessary to develop rules and guidelines for teaching technologies [20].

Researchers Paek \& Hoffman assessed students' perception of simulators in the educational process and came to the conclusion that not only professional competencies, but also soft skills are formed: the ability to work in a team, critical thinking, the ability to quickly respond to a non-standard situation [14].

Sierra provides an analysis of simulators in the field of economics and points to the main educational challenge - to go beyond traditional learning models to foster skills development, and to develop interdisciplinary approaches to improve education for urgent practical problems. The author assesses the simulator using a survey of participants (76 students). They found it particularly useful in terms of improving their knowledge, problem solving, critical thinking, and interpersonal skills. They also stated that role play is an effective way to improve affective learning outcomes [18].

Simulators in the field of management and finance are especially relevant in the educational process. Since they include working with the financial indicators of the enterprise, which in reality are a commercial secret, access to which may be limited. Moreover, simulators allow to modify various scenarios of business development, increasing the predictive ability of the model.

Such simulators can still realize the gaming potential, when a high financial result in the course of working with a simulator means victory in the competition, and, therefore, determines the winner in the simulator-simulator.

Adobor \& Daneshfar have used the business management simulator in the global sports industry. Evaluation of the effectiveness of training was carried out on the basis of a questionnaire. Research has shown that the nature of modeling and team dynamics affect learning and productivity. First, the degree to which users perceived the simulation as reflecting real life situations was positively associated with learning. Second, the ease of use of the simulation had a positive impact on learning. Third, the emotional conflict in the team was negatively associated with learning. Fourth, task conflict, as measured by the degree of exchange of ideas, was positively associated with learning [1].

Meanwhile, the authors note that the further direction in this area should be considered the development of the role of game administrators, a clear definition of their goals.

\section{RESEARCH RESULTS AND DISCUSSION}

The training simulator Business Course is aimed at covering the key issues of modern business: production management, marketing, financial management, accounting, reporting and taxation, analysis of financial and economic activities. At the same time, all issues of accounting, financial and tax reporting are reflected here in strict accordance with Russian legislation. 
The use of the simulator in the educational process included the division of students into teams - firms (10 teams of 5-6 people each). The game passed 4 rounds, meaning 4 financial years.

The winners of the rating were identified according with financial results (Table 1).

Table 1

Simulation results

\begin{tabular}{|l|r|r|r|r|r|r|r|r|r|r|}
\hline & firm 1 & firm 2 & firm 3 & firm 4 & firm 5 & firm 6 & firm 7 & firm 8 & firm 9 & firm 10 \\
\hline efficiency & & & & & & & & & & \\
\hline Net Profit & 1392559 & 512303 & 615649 & 1480037 & 128562 & 430037 & -574 & 459966 & -18269 & 381702 \\
\hline $\begin{array}{l}\text { return on } \\
\text { equity, } \\
\text { ROE }\end{array}$ & 211,2 & 223,97 & 219,37 & 218,48 & 126,51 & 150,54 & $-0,71$ & 184,73 & $-27,9$ & 186,07 \\
\hline shares & 4,209 & 3,959 & 5,192 & 12,664 & 1,5 & 4,293 & 1 & 2,837 & 1 & 2,733 \\
\hline rating & $618(+57)$ & $398(+7)$ & $478(+35)$ & $1037(+7)$ & $131(+31)$ & $349(-18)$ & $0(0)$ & $309(+180(0)$ & $286(+22)$ \\
\hline position & 2 & 4 & 3 & 1 & 8 & 5 & 9 & 6 & 9 & 7 \\
\hline
\end{tabular}

Assessment of the degree of formation of key skills was made at the beginning of the work with the stimulator, during the 1 st round, and at the end of the game, at the 4th round (Fig. 2).

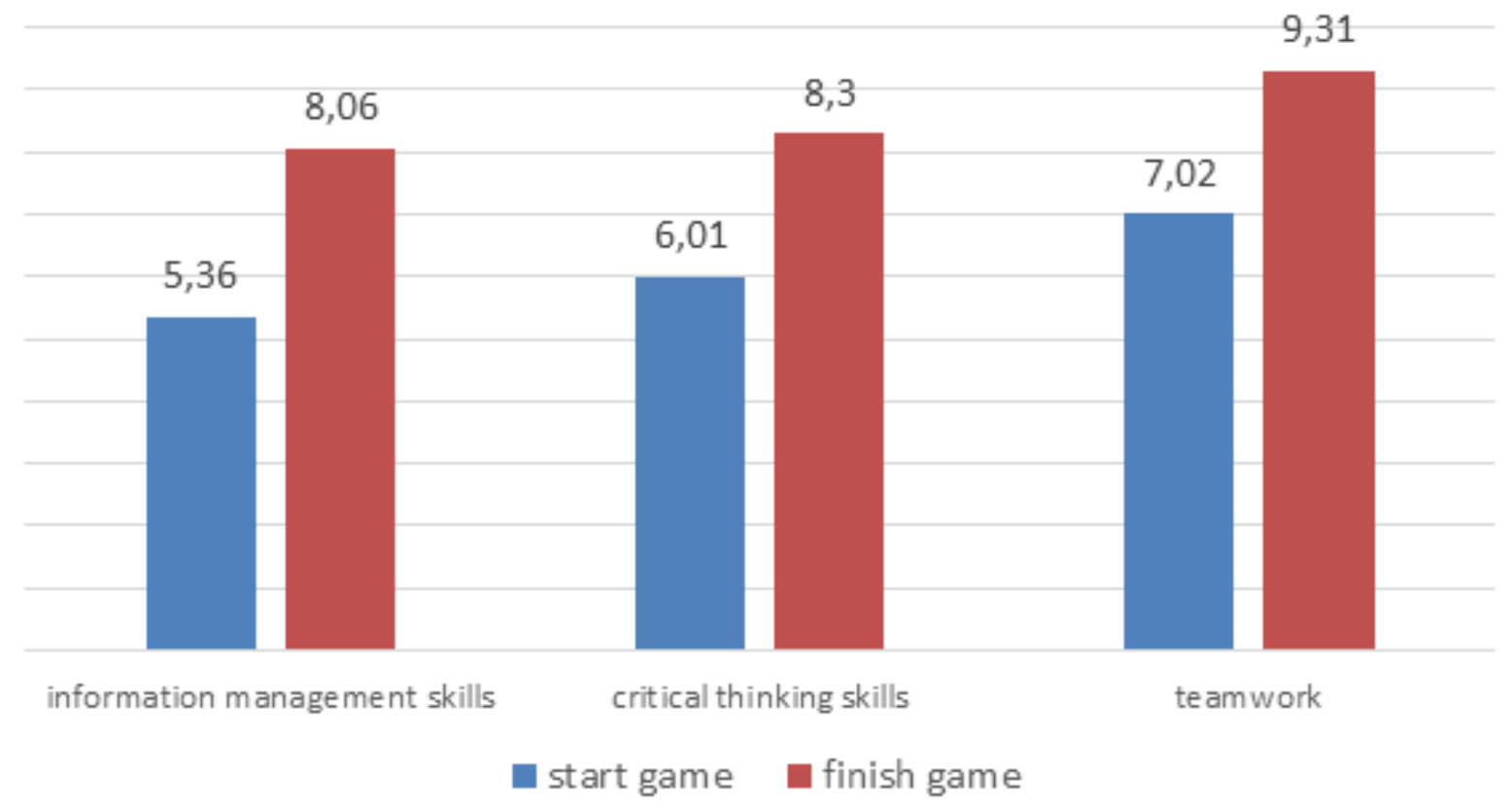

Figure 2 Average score of simulator participants

The data indicate that at the beginning of the game, communication skills were higher, combined with a lack of understanding of the relationship between decisions made and financial results, shallow critical thinking. Further participation in the business game allowed students to more successfully predict the consequences of their decisions on financial results.

It was checked whether the high rating of the participant in the game affects the learning outcomes (Fig. 3). 


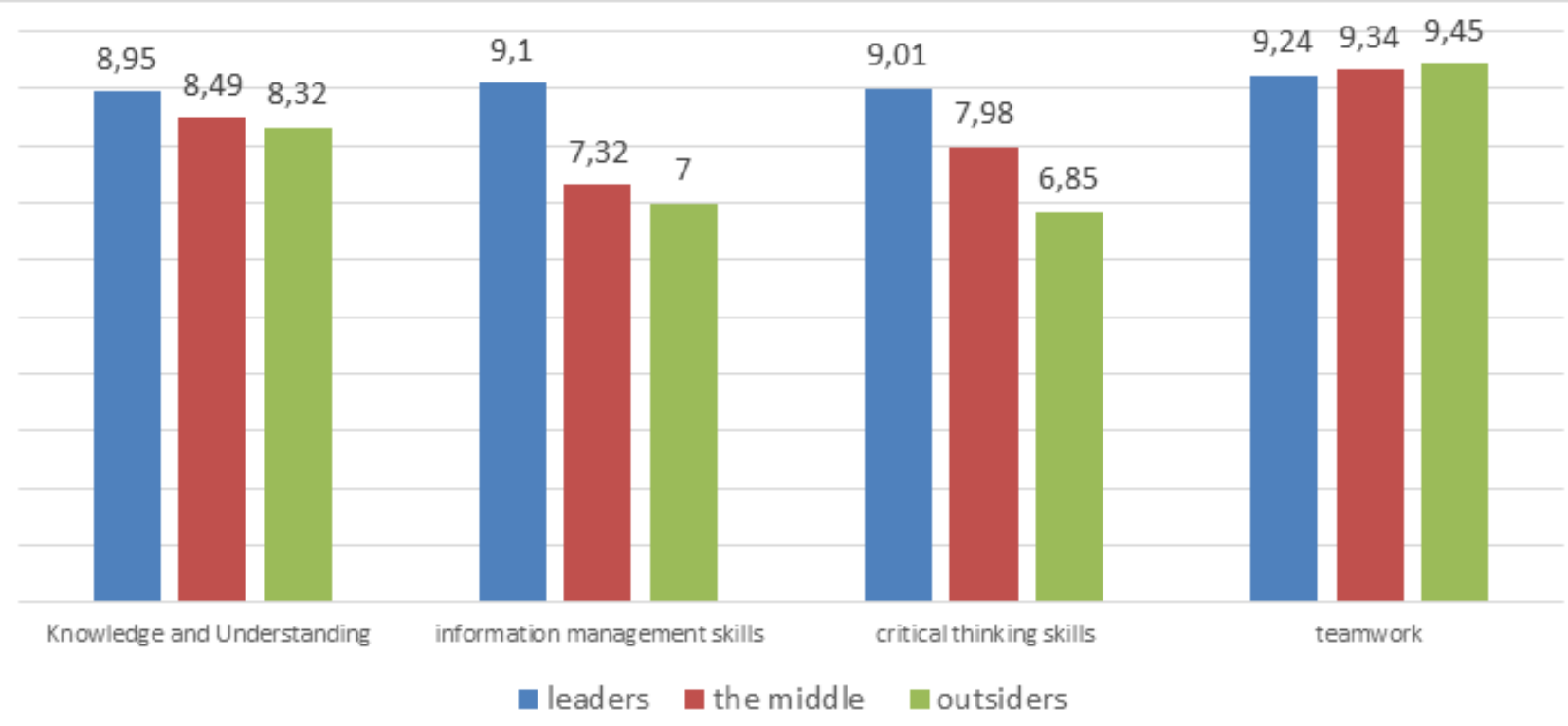

Figure 3 Educational results of using simulation

It can be seen that all participants had high communication skills and readiness to work in a team. Meanwhile, the skill of critical thinking and information management influenced the outcome of the game.

Regardless of the results of the game, the knowledge and understanding of the educational material was high among all. This means that not only the winners, but also the losers have learned the knowledge. Outsider teams noted that they understood how to act correctly towards the end of the game.

Based on the results of the training sessions, all participants were questioned using a game simulator. The questionnaire was based on the questions used in the article by Sierra [18]. The results of the questionnaire made it possible to reveal the degree of interest and involvement of students in the process of obtaining new knowledge, learning based on modern educational technologies - a business simulator.

Table 2

Student perception of the simulation

\begin{tabular}{|c|c|}
\hline Questions [18] & Answers $(n=53)$ \\
\hline 1. Do you think that simulations are a useful teaching and learning method? & $\begin{array}{l}53(100 \%) \\
0(0 \%) \\
0(0 \%)\end{array}$ \\
\hline $\begin{array}{l}\text { 2. Do you have a better understanding of the theoretical knowledge as a consequence of the } \\
\text { simulation? } \\
\text { Yes } \\
\text { No } \\
\text { Do not know }\end{array}$ & $\begin{array}{l}50(94 \%) \\
0(0 \%) \\
3(6 \%)\end{array}$ \\
\hline $\begin{array}{r}\text { 3. How useful do you think simulations are to help you to assimilate theoretical knowledge? } \\
\text { Highly useful } \\
\text { Very useful } \\
\text { Somewhat useful } \\
\text { Useful } \\
\text { Not useful }\end{array}$ & $\begin{array}{l}41(77 \%) \\
7(13 \%) \\
4(8 \%) \\
1(2 \%) \\
0(0 \%)\end{array}$ \\
\hline
\end{tabular}




\begin{tabular}{|c|c|}
\hline $\begin{array}{l}\text { 4. Do you think that your information management skills have improved as a consequence } \\
\text { of the simulation? } \\
\text { Yes } \\
\text { No } \\
\text { Do not know }\end{array}$ & $\begin{array}{l}50(94 \%) \\
1(2 \%) \\
2(4 \%)\end{array}$ \\
\hline $\begin{array}{l}\text { 5. How useful do you think simulations are to help you to improve your information } \\
\text { management skills? } \\
\text { Highly useful } \\
\text { Very useful } \\
\text { Somewhat useful } \\
\text { Useful } \\
\text { Not useful }\end{array}$ & $\begin{array}{l}41(77 \%) \\
7(13 \%) \\
3(6 \%) \\
1(2 \%) \\
1(2 \%)\end{array}$ \\
\hline $\begin{array}{l}\text { 6. Do you think that your critical thinking skills have improved as a consequence of the } \\
\text { simulation? } \\
\text { Yes } \\
\text { No } \\
\text { Do not know }\end{array}$ & $\begin{array}{l}45(85 \%) \\
3(6 \%) \\
5(9 \%)\end{array}$ \\
\hline $\begin{array}{l}\text { 7. How useful do you think simulations are to help you to improve your critical thinking } \\
\text { skills? } \\
\text { Highly useful } \\
\text { Very useful } \\
\text { Somewhat useful } \\
\text { Useful } \\
\text { Not useful }\end{array}$ & $\begin{array}{l}32(60 \%) \\
10(19 \%) \\
5(9 \%) \\
3(6 \%) \\
3(6 \%)\end{array}$ \\
\hline $\begin{array}{r}\text { 8. Do you think that your teamwork skills have improved as a consequence of the simulation? } \\
\text { Yes } \\
\text { No } \\
\text { Do not know }\end{array}$ & $\begin{array}{l}48(90 \%) \\
4(8 \%) \\
1(2 \%)\end{array}$ \\
\hline $\begin{array}{r}\text { 9. How useful do you think simulations are to help you to improve your teamwork skills? } \\
\text { Highly useful } \\
\text { Very useful } \\
\text { Somewhat useful } \\
\text { Useful } \\
\text { Not useful }\end{array}$ & $\begin{array}{l}30(57 \%) \\
17(32 \%) \\
5(9 \%) \\
1(2 \%) \\
0(0 \%)\end{array}$ \\
\hline $\begin{array}{l}\text { 10. Overall, how useful do you think this kind of simulation is for developing multiple } \\
\text { learning outcomes? } \\
\text { Highly useful } \\
\text { Very useful } \\
\text { Somewhat useful } \\
\text { Useful } \\
\text { Not useful }\end{array}$ & $\begin{array}{l}49(92 \%) \\
4(8 \%) \\
0(0 \%) \\
0(0 \%) \\
0(0 \%)\end{array}$ \\
\hline
\end{tabular}

In general, the results of the survey are consistent with the findings of Sierra [18]. In his work, he analyzed a simulator of a macroeconomic game that includes various countries that are solving problems of sustainable development. The absence of significant differences between the perception of different simulators in the present study and in Sierra's suggests that educational technology is more important in achieving educational goals.

It should be noted, that in the present study students are more positive about the simulator. Perhaps this is due to the fact that the simulator concerned the activities of the enterprise, business management, which is especially relevant and useful for all business analysts.

Meanwhile, students did not give a high enough rating to the simulator's usefulness in improving teamwork skills, believing that they were already formed with them. This can be explained by the fact that various interactive educational technologies have already been actively introduced and widely used in the educational process in university. 


\section{CONCLUSION}

As a result of the study, it can be concluded that traditional forms of educational activity require a new type of educational technology - a game business simulator. This allows not only to form professional competencies, but also soft skills required in a dynamically changing professional environment.

The results indicate the readiness of students to use new technologies in the development of professional knowledge and soft skills. This is consistent with the findings of the researchers $[1 ; 12 ; 14]$.

Meanwhile, the introduction of simulators into the educational process will require highquality methodological training, development of recommendations for game managers, as well as cooperation with real enterprises that could modify educational and practical tasks.

\section{REFERENCES}

1. Adobor, H. \& Daneshfar, A. (2006). Management simulations: Determining their effectiveness. Journal of Management Development, 25 (2), 151-168.

2. Almarashdeh, I. \& Almarashdh, I. (2016). Sharing instructors experience of learning management system: A technology perspective of user satisfaction in distance learning course. Comput. Hum. Behav., 63, 249-255.

3. Asmolov, A. G. (2009). System and Activity Approaches in the Development of a New Generation of Standards. Pedagogy, 18-22. (in Russian). Retrieved from: https://elibrary. ru/item. asp?id=12785913 (accessed 15 August 2020).

4. Byers, T., Imms, W. \& Hartnell-Young, E. (2018). Evaluating teacher and student spatial transition from a traditional classroom to an innovative learning environment. Stud. Educ. Eval., 58, 156-166.

5. Chin, J., Dukes, R., \& Gamson, W. (2009). Assessment in simulation and gaming: A review of the last 40 years. Simulation \& Gaming, 40 (4), 553-568.

6. Galustyan O. (2017). Some methodological aspects of the evaluation of students' educational achievements at university. International Journal of Cognitive Research in Science, Engineering and Education, 5 (1) (in Russian).

7. Hallinger, P. \& Wang, R. (2020). The Evolution of Simulation-Based Learning Across the Disciplines, 1965-2018: A Science Map of the Literature. Simulation and Gaming, $51(1), 9-32$.

8. Instruction for Program Complex "Business Course: Corporation plus". Retrieved from: http://www.vkkb.ru/book_vved.html (in Russian). (accessed 15 August 2020)

9. Keys, B. \& Wolfe, J. (1990). The Role of Management Games and Simulations in Education and Research, Journal of Management, 16 (2), 307-336.

10. Kirillova, N. B., Tomyuk, O. N., \& Dyachkova, M. A. (2020). Educational segment 
of modern media market: features and trends in digitalization. Economic consultant, $30(2), 48-61$.

11. Li M.-H., Hung M.-Ch., Wen-Hsu Hsian W.-H. (2019) Teaching Ecosystem Design: Teachers' Satisfaction with the Integrated Course Service System, Educ. Sci., 9 (3), 232. Retrieved from: https://doi.org/10.3390/educsci9030232 (accessed 15 August 2020)

12. Mohammadyari, S. \& Singh, H. (2015). Understanding the effect of e-learning on individual performance: The role of digital literacy. Comput. Educ, 82, 11-25.

13. National program "Digital Economy of the Russian Federation". [Elecronic resource]. Retrieved from: http://static.government.ru/media/files/3b1AsVA1v3VziZip5VzAY8RTc LEbdCct.pdf (accessed 15 August 2020) (in Russian).

14. Paek, S. \& Hoffman, D. (2018). Student Motivation for an Online Social Studies Simulation. In Proceedings of E-Learn: World Conference on E-Learning in Corporate, Government, Healthcare, and Higher Education (pp. 829-833). Las Vegas, NV, United States: Association for the Advancement of Computing in Education (AACE). Retrieved from https://www.learntechlib.org/primary/p/185038/. (accessed 15 August 2020).

15.Scopus, Analyze search results Retrieved from https://ezproxy.urfu.ru:2074/term/ analyzer.uri?sid=cb99afd9c0240602cd68f251609570cb\&origin=resultslist \&src $=\mathrm{s}$ $\& s=\% 22$ simulation + in + education $\% 22 \&$ sort $=$ plf-f $\&$ sdt $=a \&$ sot $=a \& s \mid=25 \&$ count $=79$ $1 \&$ analyzeResults $=$ Analyze+results \&txGid=1da54fc $9 f 7 f e 254787232$ abc7e $142 e 52$ (accessed 15 August 2020)

16. Shah, K. A. (2017). Game-based accounting learning: The impact of games in learning introductory accounting. International Journal of Information Systems in the Service Sector, 9 (4), 21-29.

17. Shchurov I. A. \& Vaulin S. D. (2018). Transformation of Continuing Education of Engineers under Forced Development and Information-Communication Technologies Usage. Bulletin of the South Ural State University. Ser. Education. Educational Sciences, 10 (1), 78-101 (in Russian).

18. Sierra, J. (2020) The potential of simulations for developing multiple learning outcomes: The student perspective. International Journal of Management Education, 18 (1).

19.Stosić, L. (2015). The importance of educational technology in teaching. International Journal of Cognitive Research in Science, Engineering and Education (IJCRSEE), 3 (1), 111-114. Retrieved from http://ijcrsee.com/index.php/ijcrsee/article/view/166 (accessed 15 August 2020)

20. Ullah A. Sh. (2019) Fundamental Issues of Concept Mapping Relevant to DisciplineBased Education: A Perspective of Manufacturing Engineering, Educ. Sci., 9 (3), 228. doi: 10.3390/educsci9030228 


\section{INFORMATION ABOUT THE AUTHORS}

1. Anna V. Diachkova (Russia, Ekaterinburg) - Associate Professor, PhD in Economics, associate Professor of the Department of Economic Theory and Economic Policy. Ural Federal University named after the first President of Russia B. N. Yeltsin. E-mail: a.v.diachkova@urfu.ru. Scopus ID: 57211156711

2. Daniil G. Sandler (Russia, Ekaterinburg) - PhD in Economic Sciences, Associate Professor of the Department of Financial Management, Leading Researcher, Research Laboratory for University Development Issues, Vice-Rector (Economics and Strategy). Ural Federal University named after the First President of Russia B. N. Yeltsin. E-mail: d.g.sandler@urfu.ru. Scopus ID: 56581474400

3. Elena S. Avramenko (Russia, Ekaterinburg) - Associate professor, PhD in Economics, associate Professor of the Department of International Economics and Management, Vice-Director of Academic Affairs. Ural Federal University named after the first President of Russia B. N. Yeltsin. E-mail: e.s.avramenko@urfu.ru. Scopus ID: 56582172000 